\title{
Ekspor dan daya saing cassiavera Indonesia - China di Pasar Internasional
}

\author{
Nurhayani*; Dearmi Artis; Parmadi \\ Prodi Ekonomi Pembangunan, Fak. Ekonomi dan Bisnis, Universitas Jambi \\ *E-mail korespodensi: nurhayani@unja.ac.id
}

\begin{abstract}
The plantation sector is a major sector that has an important role in Indonesia both in terms of increasing income and in balancing environmental preservation and as an instrument of equitable development of the people. One of the commodities in the plantation sector is Cassiavera. This study aims to determine and analyze the effect of area, production, exchange rate and economic growth on the export volume of Cassiavera. This study uses secondary data and uses the ECM and RCA analysis tools. In the long run, all variables, either simultaneously or partially, affect the Cassiavera export variable. Whereas in the short term partially or individually, only the economic growth variable affects Cassiavera exports and simultaneously or together all variables affect Cassiavera exports. Indonesian Cassiavera has greater competitiveness than China, which is shown by Indonesia's higher RCA value than China.
\end{abstract}

Keywords: Cassiavera exports, Competitiveness

\begin{abstract}
Abstrak
Sektor perkebunan merupakan sektor utama yang mempunyai peran penting di Indonesia baik dalam hal meningkatkan pendapatan maupun dalam penyeimbang pelestarian lingkungan hidup serta sebagai instrumen pemerataan pembangunan rakyat. Salah satu komoditi sektor perkebunan adalah Cassiavera. Penelitian ini bertujuan mengetahui dan menganalisis pengaruh luas area, produksi, nilai tukar dan pertumbuhan ekonomi terhadap volume ekspor Cassiavera. Penelitian ini menggunakan data sekunder dan menggunakan alat analisis ECM dan RCA. Dalam jangka panjang seluruh variabel baik simultan maupun parsial mempengaruhi variabel ekspor Cassiavera. Sedangkan dalam jangka pendek secara parsial atau individu hanya variabel pertumbuhan ekonomi yang mempengaruhi ekspor Cassiavera dan secara simultan atau bersama-sama seluruh variabel berpengaruh terhadap ekspor Cassiavera. Cassiavera Indonesia memiliki daya saing yang lebih besar daripada China yang ditunjukan dari nilai RCA indonesia lebih tinggi dari China.
\end{abstract}

Kata kunci : Ekspor Cassiavera, Daya saing

\section{PENDAHULUAN}

Cinnamomum burmannii Blume merupakan spesies Cassiavera yang dikenal sebagai 'padang kaneel' atau 'cassiavera'. Cassiavera terdapat di hampir seluruh wilayah di Indonesia diantaranya Pulau Sumatera, tersebar di sepanjang pegunungan Bukit Barisan, mulai dari Aceh, Sumatera Utara, Sumatera Barat, Jambi, Bengkulu sampai ke 
Lampung dan Pulau Jawa serta Kalimantan (Nurhayani dan Rosmeli, 2019). Berdasarakan data Faostat (2018) total Luas lahan perkebunan Cassiavera Indonesia pada tahun 2017 mencapai 105.530 hektar yang merupakan lahan perkebunan rakyat. Cassiavera Indonesia merupakan primadona di mancanegara namun kini tengah menghadapi persaingan internasional, bukan hanya Cina akan tetapi dengan Negara produsen lainnya seperti SriLanka, Madagaskar dan Granada, juga di kawasan Asean seperti Vietnam dan Filipina. Volume ekspor Cassiavera Indonesia pada tahun 2017 sebanyak 148.076 ton, naik tajam dari tahun sebelumnya yaitu sebanyak94.155 ton.

Ekspor Cassiavera berperan penting dalam perekonomian Indonesia. Karena dari permintaanya Cassiavera Indonesia sangat dibutuhkan di negara seperti Amerika Serikat. Menurut Ayuningsih (2014) ekspor Cassiavera Indonesia ke Amerika Serikat lebih unggul dibandingkan dengan ekspor dari China periode tahun 1992 hingga 2011. Walaupun pada akhir-akhir ini harga Cassiavera Indonesia mengalami fluktuasi yang menyebabkan ketidakpastian pendapatan petani Cassiavera Indonesia. Menurut Arifin (2013) tantangan yang dihadapi oleh komoditas ekspor pertanian Indonesia masih cukup besar, seperti petani kecil yang menghasilkan sistem tanaman yang rendah, tekanan keberlanjutan, kualitas produksi rendah, rendahnya investasi, infrastruktur yang tidak memadai, praktik pertanian yang kurang berkembang dan kebijakan pemerintah. Namun tidak dipungkiri bahwa Cassiavera Indonesia masih tetap dibutuhkan dalam pasar internasional. Dalam perspektif jangka panjang, diperlukan kestabilan perkembangan ekspor Cassiavera Indonesia, sehingga perlu ditingkatkan kinerja ekspor Cassiavera Indonesia yaitu perkembangan, kontribusi serta daya saingnya, untuk itu penelitian ini akan menganalisis ekspor dan daya saing Cassiavera Indonesia - Cina di pasar internasional.

Cassiavera atau Cinnamon merupakan komoditas unggulan berpotensial yang di ekspor oleh Indonesia. Sesuai dengan tujuan pemerintah yang menjadikan Cassiavera sebagai salah satu komoditas unggulan. Produksi Cassiavera yang cukup besar membuat Indonesia menjadi negara yang mengekspor Cassiavera terbanyak di dunia. Namun masih mengalami flutuasi baik produksi maupun volume ekspornya pada saat ini. Kondisi volume ekspor Cassiavera yang masih mengalami fluktuasi dan belum stabil setiap tahunya menunjukan bahwa peningkatan pengembangan komoditas Cassiavera masih belum maksimal. Peningkatan suatu komoditas ekspor Indonesia itu tidak terlepas dari semakin tingginya produktifitas dan kinerja ekspor tersebut. Kinerja disini biasanya terlihat dari perkembangan dalam negeri, kontribusi serta daya saingnya. Mengingat Indonesia masih memiliki peluang yang besar dan memiliki keunggulan komparatif di banding negara lain dalam upaya peningkatan ekspor Cassiavera sehingga diperlukan penganalisisan mengenai daya saing dan faktor yang mempengaruhi ekspor Cassiavera. Adapun variable yang digunakan adalah luas area, produksi, nilai tukar rupiah, pertumbuhan ekonomi dan volume ekspor Casaiavera di Indonesia

Haryadi (2014) dalam bukunya menjelaskan ada beberapa teori yang menjelaskan tentang perdagangan internasional yaitu:

\section{Teori keuntungan absolut}

Teori keuntungan absolut diperkenalkan oleh Adam Smith, Menurut Smith, kemakmuran suatu negara bukanlah hanya terletak pada banyaknya logam mulia yang ditimbun oleh suatu negara. akan tetapi tergantung pada banyaknya jumlah barang yang dimilikinya. Tan (2014) pada prinsipnya teori Adam Smith menjelaskan suatu negara 
yang kaya dengan tenaga kerja lebih menguntungkan memproduksi dan mengekspor produk yang padat tenaga kerja dan mengimpor produk yang padat modal atau padat teknologi karena negara tersebut akan mendapatkan keuntungan mutlak yang berupa selisih harga antara produk yang di ekspor dengan yang diimpor. Fungsi produksi hanya mempunyai satu input tenaga kerja, input lain diangggap konstan.

\section{$\mathbf{Q}=\mathbf{f}(\mathbf{L}) \operatorname{dimana} \Delta \mathbf{Q} / \Delta \mathbf{L}>\mathbf{0}$}

Kenaikan tenaga kerja akan meningkatkan output dan terjadi sebaliknya dengan menurunya pemakaian tenaga kerja.

\section{Teori keunggulan komparatif}

Pada abad ke 19, David Ricardo memperkenalkan teori keuntungan komparatif, keuntungan keunggulan komparatif adalah keunggulan atau kemampuan yang dimiliki untuk menghasilkan barang-barang dengan tingkat harga relatif yang lebih rendah dari barang lainnya. Keunggulan komparatif menjelaskan perdagangan dapat menguntungkan negara melalui penggunaan sumber daya (tanah, tenaga kerja, masukan modal) yang lebih efisien pada saat produksi pasar dunia terbatas. Setiap negarah arus memproduksi dan mengekspor produk yang memiliki keunggulan komparatif, yaitu komoditas memiliki kualitas tertentu tetapi dihasilkan dengan rasio biaya input yang lebih rendah dibandingkan dengan produksi di negara lain (Firmansyah dkk, 2017).

\section{Teori ongkos komparatif}

Pada prinsipnya teori ini hampir sama dengan teori dari David Ricardo yaitu: masing-masing negara mengekspor barang yang memiliki keunggulan komparatif tanpa memperhatikan apakah negara itu memperoleh keunggulan mutlak. Masing-masing negara dapat menghasilkan suatu satuan barang ekspornya lebih murah pada satu satuan barang yang diimpornya, seandainya barang tersebut dihasilkan nya sendiri..

Sumber utama perdagangan internasional adalah perbedaan sumber daya yang oleh masing-masing negara yang mempengaruhi perdagangan internasional Teori ini dikembangkan oleh dua ekonom terkemuka dari Swedia, Eli Heckscher dan Bertil Ohlin sehingga terkenal sebagai teori Heckscher-Ohlin. Hal ini juga dikenal sebagai teori proporsi faktor dan teori faktor en-dowment. Hal ini karena dua teori menekankan pada perbedaan faktor proporsi pada setiap negara dan perbedaan yang digunakan dalam memproduksi barang (Ridwanullah dan Sunaryati, 2018).

Teori keunggulan komparatif berubah menjadi teori keunggulan kompetitif yang dikembangkan oleh Porter, dimana produk ekspor tidak hanya diukur dalam jangka waktu biaya tenaga kerja dan ketersediaan sumber daya alam tetapi juga didorong oleh faktor lain, yaitu: produk teknologi, kualitas produk, desain dan promosi produk, serta fasilitas penunjang infrastruktur, yang pada gilirannya akan menurunkan biaya produksi dan meningkatkan kualitas produk ekspor (Tan dan Firwan, 2017).

\section{METODE}

Metode yang digunakan dalam penelitian ini adalah metode penelitian deskriptif kuantitatif naratif dengan menggunakan data sekunder dikarenakan penelitian ini 
bersifat menggambarkan, menghitung, menguraikan, serta menarasikan dalam bentuk naskah hasil penelitian tersebut.

\section{Model analisis data}

Analisis kuatitatif digunakan untuk melihat bagaimana pengaruh variabel bebas (Luas Area, Produksi, Nilai Tukar Rupiah/US\$, Pertumbuhan Ekonomi) terhadap variabel terikat yaitu volume ekspor Cassiavera Indonesia atau untuk menjawab permasalah yang kedua pada penelitian ini dengan menggunakan metode Error Corection Model (ECM). Wooldridge (2009) menyatakan sebuah model ECM memungkinkan untuk mempelajari dinamika jangka pendek dan jangka panjang dalam hubungan variabel bebas dan variabel terikat metode ECM digunakan untuk menyeimbangkan hubungan ekonomi jangka pendek dengan variabel yang memiliki hubungan ekonomi jangka panjang.

Model persamaannya adalah sebagai berikut :

XC = f(LA, PROD, NTR, PE)

Dimana:

$\mathrm{X}_{\mathrm{C}} \quad=$ Ekspor cassiavera Indonesia terlihat dari volume ekspor

LA = Luas lahan cassiavera dunia

PROD = Produksi cassiavera Indonesia

NTR = Nilai tukar rupiah / US\$

$\mathrm{PE} \quad=$ Pertumbuhan ekonomi

Model umum Error Correction Model adalah sebagai berikut : (Winarno, 2015)

$$
\Delta Y=\alpha+\alpha 1 \Delta X t+b 2 E C t-1+\text { et }
$$

Model yang digunakan dalam penelitian ini adalah model ekonometrika dengan model awalnya adalah :

$$
\mathrm{X}_{\mathrm{t}}=\alpha+\alpha_{1} \mathrm{LA}_{\mathrm{t}}+\alpha_{2} \mathrm{PROD}_{\mathrm{t}}+\alpha_{3} \mathrm{NTR}_{\mathrm{t}}+\alpha_{4} \mathrm{PE}_{\mathrm{t}} \mathrm{e}_{\mathrm{t}}
$$

\section{Analisis daya saing}

Untuk menganalisis daya saing digunakan konsep advantageis komparatif adalah indeks RCA.

Rumus matematis sebagai berikut : (Tan, 2013)

$R C A=\frac{X i j / X i t}{W i j / W i t}$

Dimana: Xij = Jumlah/nilai ekspor Cassiavera Indonesia

Xit $=$ Jumlah/nilai total ekspor Indonesia

Wij = Jumlah/nilai ekspor Cassiavera dunia

Wit $=$ Jumlah/nilai total ekspor dunia

\section{HASIL DAN PEMBAHASAN}

\section{Analisis kuantitatif}

Analisis kuantitatif digunakan untuk mengetahui bagaimana pengaruh variabel volume ekspor terhadap luas area, produksi, nilai tukar rupiah dan pertumbuhan 
ekonomi baik dala jangka pendek maupun jangka panjang dengan menggunakan metode ECM (Error Corection Model).

\section{Uji stasioneritas}

\section{Uji akar-akar unit (Unit Root Test)}

Hasil uji stasioneritas data pada tingkat level menunukan bahwa semua variabel terdapat unit root atau data tidak stasioner pada tingkat level kecuali pada variabel pertumbuhan ekonomi. Terlihat dari nilai t-stat $<\mathrm{t}$ kritis. Sehingga perlu pengujian lanjutan pada uji derajat integrasi.

Tabel 1. Hasil uji stasioneritas pada tingkat level pengamaatan periode 1989-2017

\begin{tabular}{cccccc}
\hline Variabel & $\begin{array}{c}\text { Metode } \\
\text { pengujian }\end{array}$ & t-stat & $\boldsymbol{t}$-crit & $\begin{array}{c}\text { Probabilita } \\
(\boldsymbol{p} \text {-value })\end{array}$ & Interpretasi \\
\hline VX & ADF & -1.821559 & -2.971853 & 0.3628 & Data tidak stasioner \\
LA & ADF & -0.992580 & -2.971853 & 0.7418 & Datatidak stasioner \\
PROD & ADF & -1.200161 & -2.971853 & 0.6599 & Data tidak stasioner \\
NTR & ADF & -0.812364 & -2.991853 & 0.8000 & Data tidak stasioner \\
PE & SDF & -3.736321 & -2.971853 & 0.0089 & Data stasioner \\
\hline
\end{tabular}

Sumber. Data diolah, 2020

\section{Uji derajat integrasi}

Berdasarkan hasil uji derajat integrasi pada tingkat pertama atau First Difference yang menunjukan bahwa seluruh variabel volume ekspor, luas area, produksi, nilai tukar rupiah dan pertumbuhan ekonomi diterima atau stasioner pada tingkat pertama. Terbukti bahwa t-kritis $<\mathrm{t}$-stat dan $p$-value $<\alpha$. Setelah seluruh variabel stasioner maka dilanjutkan dengan pengujian kointegrasi.

Tabel 2. Uji stasioneritas tingkat first difference pengamatan periode 1989-2017

\begin{tabular}{cccccc}
\hline Variabel & $\begin{array}{c}\text { Metode } \\
\text { pengujian }\end{array}$ & t-stat & t-kritis & $\begin{array}{c}\text { Probabilita } \\
(\boldsymbol{p} \text {-value })\end{array}$ & Interpretasi \\
\hline VX & ADF & -4.931110 & -2.976263 & 0.0005 & Data stasioner \\
LA & ADF & -6.101065 & -2.976263 & 0.0000 & Data stasioner \\
PROD & ADF & -3.892767 & -2.976263 & 0.0063 & Data stasioner \\
NTR & ADF & -5.125884 & -2.976263 & 0.0003 & Data stasioner \\
PE & SDF & -6.499366 & -2.976263 & 0.0000 & Data stasioner \\
\hline
\end{tabular}

Sumber. Data diolah, 2020

\section{Uji kointegrasi}

Uji kointegari ini merupakan salah satu syarat untuk melanjutkan ketahap berikutnya yaitu dengan menggunakan metode ECM, residualnya harus stasioner pada tingkat level.

Berdasarkan hasil pengujian pada Tabel 3 residual dari persamaan regresi stasioner di tingkat level pada tingkat keyakinan 5\%. Hal ini terlihat dari nilai t-sta lebih 
besar dari nilai t-crit yaitu -3.265516> -2.971853 dan probabilita 0.0265 lebih kecil dari 0.05 (tingkat keyakinan 5\%). Setelah didapatkan stsionerita data ECT pada tingkat level maka dapat dilanjutkan dengan pengujian regresi jangka pandajng dan jangka pendek atau ECM.

Tabel 3. Hasil pengujian unit root terhadap residual persamaan regresi

\begin{tabular}{lllll}
\hline Residual & t-sta & t-crit & Probability & Keterangan \\
\hline ADF & -3.265516 & -2.971853 & 0.0265 & Data stasioner
\end{tabular}

Sumber. Data diolah, 2020

Regresi jangka panjang

Hasil regresi dari jangka panjang ditunjukan pada Tabel 4 dibawah ini :

Tabel 4. Estimasi jangka panjang

\begin{tabular}{crrrrr}
\hline Variabel & Coefficient & Std.error & t-statistic & Probabilita & $\begin{array}{c}\text { Prob } \\
\text { f-statistik }\end{array}$ \\
\hline C & 225969.4 & 52541.47 & 4.300782 & 0.0002 & \\
LA & -4.872888 & 1.742375 & -2.796693 & 0.0100 & \\
PROD & 3.458719 & 0.983735 & 3.515905 & 0.0018 & 0.000002 \\
NTR & 24.31864 & 8.214084 & 2.960603 & 0.0068 & \\
PE & -10.46267 & 3.741457 & -2.796416 & 0.0100 & \\
\hline
\end{tabular}

Sumber. Data diolah, 2020

Maka persamaan model yang diperoleh adalah sebagai berikut:

$$
\mathrm{VX}_{\mathrm{t}}=225969.4-4.8728 \mathrm{LA}_{\mathrm{t}}+3.4587 \mathrm{PROD}_{\mathrm{t}}+24.3186 \mathrm{Ntr}_{\mathrm{t}}-10462.67 \mathrm{PE}_{\mathrm{t}}+\varepsilon_{\mathrm{t}}
$$

Dalam persamaan jangka panjang didapatkan bahwa seluruh variabel bebas berpengaruh terhadap variabel terikat dengan nilai probabilita yang lebih kecil dari tingkat keyakinan 5 persen.

Setelah dilakukan uji persyaratan untuk menentukan model estimasi, diketahui bahwa data bersifat stationer pada tingkat level dan terjadi kointegrasi maka model selanjutnya dengan menggunakan estimasi ECM untuk melihat jangka pendek.

\section{Regresi jangka pendek (ECM)}

Hasil estimasi pada Tabel 5 menunjukan dalam jangka pendek probabilita untuk variabel pertumbuhan ekonomi dan ECT signifikan pada tingkat keyakinan 5\%. Sedangkan variabel luas area, produksi dan ntr untuk jangka pendek tidak signifikan pada tingkat keyakinan 5\% . Nilai ECT signifikan secara statistik berarti model spesifik ECM yang digukanakan adalah valid. nilai koefisien ECT sebesar 0.4389 menunjukan bahwa fluktuasi keseimbangan jangka pendek akan dikoreksi menuju keseimbangan 
jangka panjang, dimana sekitar $43,89 \%$ proses adjustment-nya terjadi pada tahun pertama dan $56,11 \%$ proses adjustment terjadi pada tahun berikutnya.

Tabel 5. Hasil regresi Model ECM (jangka pendek)

\begin{tabular}{crrrr}
\hline Variabel & Coefficient & Std.error & t-statistic & Probabilita \\
\hline C & -3023.237 & 10051.65 & -0.300770 & 0.7664 \\
D(LA) & 1.038270 & 1.784820 & 0.581723 & 0.5667 \\
D(PROD) & 1.400016 & 1.138164 & 1.230066 & 0.2317 \\
D(NTR) & 8.920932 & 8.845586 & 1.008518 & 0.3242 \\
D(PE) & -7.341406 & 2.240867 & -3.276145 & 0.0035 \\
ECT(-1) & -0.438900 & 0.164651 & -2.665635 & 0.0141 \\
\hline
\end{tabular}

Sumber. Data diolah, 2020

Persamaan Model yang didapatkan adalah sebagai berikut:

$\operatorname{LogVX}_{\mathrm{t}}=0-3023.23+1.0382 \mathrm{LA}_{\mathrm{t}}+1.40001 \mathrm{PROD}_{\mathrm{t}}+8.9209 \mathrm{NTR}_{\mathrm{t}}-7.3410 \mathrm{PE}_{\mathrm{t}}-0.4389 \mathrm{ECT}_{\mathrm{t}}+\varepsilon_{\mathrm{t}}$

$$
\begin{array}{lllll}
(0.5667) & (0.2317) & (0.3242) & (0.0035) & (0.0141)
\end{array}
$$

Koefisien pertumbuhan ekonomi berpengaruh signifikan dan negatif dengan nilai t statistic sebesar 3.2761 dan probabilita 0.0035 lebih kecil dari tingkat alfa 0,05 dan dengan nilai koefisien adalah sebesar 7.3410. artinya jika pertumbuhan ekonomi mengalai perubahan sebesar 1 persen maka ekspor Cassiavera akan berkurang sebesar 7.3410 persen dengan asumsi variabel lain tetap.

\section{Uji hipotesis}

\section{Uji signifikan simultan (Uji F)}

Sesuai hasil analisis, dalam jangka panjang diperoleh nilai F-hitung sebesar 15.56448 dan probabilita $\mathrm{F}$ sebesar 0.000002 dan dalam jangka pendek diperoleh nilai F-hitung sebesar 5.303042 dan probabilita F sebesar 0.002402 dalam taraf signifikan 5\% maka uji $\mathrm{F}$ dapat disimpulkan bahwa dalam jangka panjang dan jangka pendek seluruh variabel baik luas are, produksi, nilai tukar rupiah dan pertumbuhan ekonomi secara simultan atau bersama-sama mempengaruhi ekspor Cassiavera Indonesia.

a. Uji Signifikan Parsial (Uji t)

Koefisien luas area berpengaruh signifikan dan negatif dengan didapatkan nilai $\mathrm{t}$ statistik sebesar 2.7966 dengan probabilitannya sebesar 0.0100 yang lebih kecil dari tingkat keyakinan 5 persen atau 0,05. dengan nilai koefisien sebesar 4.8728 artinya jika luas area berubah 1 persen maka volume ekspor akan berkurang sebesar 4.8728 persen dalam jangka panjang dengan asumsi variabel lain tetap. Pengaruh negative dari luas area disini disebabkan dengan adanya beberapa masalah yang ada di lahan seperti rusaknya lahan tanaman yang disebabkan oleh curah hujan yang tinggi dan strutur tanah yang rusak sehingga berdampak pada kurang produktif hasil tanaman ( Ayuningsih, 2014).

Hasil uji koefisien produksi yaitu dengan t hitung 3.5159 yang memiliki probabilita 0.0018 yang lebih kecil dari 0,05 artinya jumlah produksi berpengaruh 
signifikan dan positif. dengan nilai koefisien adalah 3.4587 artinya jika produksi naik 1 persen maka ekspor Cassiavera akan meningkat sebesar 3.4587 persen secara rata-rata dalam jangka panjang dengan asumsi variabel lain tetap. Seperti yang dilakukan dalam penelitian sebelumnya oleh Radifan 2014, bahwa dalam jangka panjang produksi berpengaruh terhadap ekspor CPO Indonesia.

Dilihat dari thitung koefisien ntr sebesar 2.9606 dengan probabilita 0,0068 yang lebih kecil dari 0,05 yang berarti nilai tukar rupiah terhadap dollar Amerika berpengaruh signifikan dan positif. Dengan nilai koefisien adalah 24.3186 artinya jika nilai tukar rupiah terhadap dollar mengalami depresiasi dalam jangka panjang sebesar 1 persen maka ekspor Cassiavera akan meningkat sebesar 24.3186 persensecara rata-rata dala jangka panjang dengan asumsi variabel lain tetap.

Koefisien pertumbuhan ekonomi berpengaruh signifikan dan negatif terlihat dari nilai t statistic sebesar -2.796416 dengan probabilita yang sebesar 0.0100 lebih kecil dari tingkat alfa 0.05 dengan nilai koefisien adalah 10.4626. artinya jika pertumbuhan ekonomi naik 1 persen maka ekspor Cassiavera akan berkurang sebesar 10.4626 persen dengan asumsi variabel lain tetap.

Sedangkan dalam jangka pendek hanya variabel pertumbuhan ekonomi dan ECT yang berpengaruh signifikan terhadap ekspor Cassiavera Indonesia. Hasil estimasi pada tabel menunjukan dalam jangka pendek probabilita untuk variabel pertumbuhan ekonomi dan ECT signifikan pada tingkat keyakinan 5\%. Sedangkan variabel luas area, produksi dan ntr untuk jangka pendek tidak signifikan pada tingkat keyakinan $5 \%$. Nilai ECT signifikan secara statistik berarti model spesifik ECM yang digukanakan adalah valid. nilai koefisien ECT sebesar 0.4389 menunjukan bahwa fluktuasi keseimbangan jangka pendek akan dikoreksi menuju keseimbangan jangka panjang, dimana sekitar $43,89 \%$ proses adjustment-nya terjadi pada tahun pertama dan $56,11 \%$ proses adjustment terjadi pada tahun berikutnya.

Koefisien pertumbuhan ekonomi berpengaruh signifikan dan negatif dengan nilai t statistic sebesar 3.2761 dan probabilita 0.0035 lebih kecil dari tingkat alfa 0,05 dan dengan nilai koefisien adalah sebesar 7.3410. artinya jika pertumbuhan ekonomi mengalai perubahan sebesar 1 persen maka ekspor Cassiavera akan berkurang sebesar 7.3410 persen dengan asumsi variabel lain tetap.

\section{Koefisien determinasi $\left(\mathbf{R}^{2}\right)$}

Didapatkan hasil $\mathrm{R}^{2}$ dalam jangka panjang sebesar 0,7218 atau senilai 72,18 persen. Menunjukan bahwa kemampuan variabel luas area, produksi, nilai tukar rupiah dan pertumbuhan ekonomi dalam menjelaskan variabel ekspor Cassiavera dalam jangka panjang sebesar 72,18 persen sedangkan sisanya sebesar 27,82 persen dijelaskan oleh variabel lain yang tidak diteliti atau dijelaskan dalam penelitian ini. Sedangkan dalam jangka pendek nilai $\mathrm{R}^{2}$ adalah 0.5465 atau 54,65 persen yang berarti kemampuan variabel luas area, produksi, nilai tukar rupiah dan pertumbuhan ekonomi dalam menjelaskan variabel ekspor Cassiavera dalam jangka pendek adalah sebesar 54,65 persen sedangkan sisanya dipengaruhi oleh variabel lain yang tidak diteliti.

\section{Analisis daya saing}

Analisis daya saing dengan menggunakan perhitungan RCA (Revealed Comparative Advantage) antara Indonesia dan China periode 2000 sampai dengan 2018. Data yang diperoleh bahwa seluruh hasil indeks RCA baik Indonesia maupun 
China adalah lebih besar dari 1. Hasil perhitungan menunjukan bahwa ekspor Cassiavera Indonesia dan China secara individual memiliki daya saing di dunia atau pasar Internasional yang cukup tinggi. rata-rata RCA Indonesia lebih besar dibadingkan dengan rata-rata RCA China. Hal ini didorong dari jumlah produksi serta ekspor Cassiavera yang banyak dari Indonesia dibandingkan dengan China periode 2000 sampai dengan 2018. Dengan besarnya RCA yang diperoleh hal ini juga dapat disimpulkan bahwa Cassiavera Indonesia memberikan kontribusi yang cukup tinggi terhadap devisa perdagangan Negara. Seperti dalam penelitian.

\section{KESIMPULAN SAN SARAN}

\section{Kesimpulan}

Faktor-faktor yang mempengaruhi ekspor Cassiavera dala jangka panjang adalah luas area, produksi, nilai tukar rupiah dan pertmbuhan ekonom. Sedangkan dalam jangka pendek hanya pertumbuhan ekonomi dan residual ECT yang berpengaruh terhadap ekspor Cassiavera. Secara bersama-sama luar area, produksi, nilai tukar rupiah dan pertumbuhan ekonomi berpengaruh signifikan terhadap Cassiavera baik jangka panjang maupun jangka pendek. Indonesia dan China Memiliki daya saing yang cukup tinggi di pasar Internasional. Daya daing ekspor Cassiavera Indonesia lebih besar dibandingkan dengan China dengan rata-rata RCA Indonesia adalah 19,1 sedangkan China adalah 2,7.

\section{Saran}

Pemerintah dapat menjaga kestabilan dan meningkatkan ekspor Cassiavera Indonesia. Dan dapat meningkatkan produksi dengan memperluas area penanaman Cassiavera dan memanfaatkan teknologi yang ada, dan mempertahankan nilai tukar rupiah agar tetap stabil. Selain itu pemerintah juga dapat terus mengembangkan produk turunan dari Cassiavera agar terus dapat bersaing di pasar dunia tidak hanya bahan mentah tetapi juga produk olahan. Tingginya daya saing Cassiavera menunjukan bahwa Cassiavera Indonesia dapat bersaing di pasar dunia, sehigga pemerintah harus dapat terus meningkatkan Cassiavera Indonesia dengan meningkatkan ekspor Cassiavera. Untuk ilmuwan dan akademisi serta peneliti, dapat menambah variabel lain sebagai variabel bebas, atau dapat menambah tahun pengamatan (time series) sehingga dapat hasil regresi dalam dalam jangka pendek tentang signifikansi pengaruh variabel bebas.

\section{DAFTAR PUSTAKA}

Arifin, Bustanul. (2013). On the competitiveness and sustainability of the indonesian agricultural export commodities. ASEAN Journal of Economics, Management and Accounting, 1(1), 81-100.

Ayuningsih, Ni Luh dan N.Djinar. (2014). Pengaruh kurs dollar Amerika Serikat, jumlah produksi dan luas lahan terhadap volume ekspor kayu manis Indonesia Periode 1992-2011 serta daya saingnya. E-Jurnal Ekonomi Pembangunan Universitas Udayana, 2(8), 366-375

Firmansyah, Wahyu dkk. (2017) Export performance and competitiviness of Indonesia Food Commodities. Journal of Economics and Policy, 10(2), 289-301.

Girsang, (2019). Error correction model for pakistan export demand for indonesia's crude palm oil (CPO). Journal of Agricultural Sciences, 1(2), 68-77 
Haryadi. (2014). Ekonomi Internasional teori dan aplikasi. Bogor: Biografika Nurhayani dan Rosmeli. (2019). Guncangan harga dan pangsa pasar ekspor cassiavera Kabupaten Kerinci. Jurnal Sains Sosio dan Humaniora, 3(2),189-197

Ridwannullah dan Sunaryati. (2018). Determinants of Indonesian crude palm oil export:gravity model approach. Jurnal Ekonomi dan Studi Pembangunan, 19(2), 134-141

Tan, Syamsurijal. (2014). Perdagangan Internasional (Teori dan Beberapa Aplikasi). CV Bukit Mas: Jambi

Tan, Syamsurizal dan Firwan. (2017). Indonesian crude palm oil export performance during the Period (1990Q1-2015Q4). Journal of Agricultural Science and Soil Sciences, 5(8), 152-165

Wooldridge, Jefferey M. (2009). Introdustory Econometrics, Fourth Edition. SouthWestern Cengage Learning: USA 